\title{
IDENTIFYING THE IMPACT OF INFORMATION LOGISTICS ON CONTEMPORARY CONCEPTIONS OF LOGISTICS
}

\begin{abstract}
The contemporary economy is characterized by high reliance on modern technology, IT systems, and analyses of large amounts of information and data. This reliance promotes creation of new, innovative logistics concepts. Many practitioners and scientists have described the current situation as a logistics revolution, logistics 4.0 or logistics of the $21^{\text {st }}$ century. This article attempts to systematize this terminology and present the foundation of modern strategies within logistics. What influenced the creation and functioning of the contemporary logistics strategies was the logistics of information and rationalization processes occurring within it. The aim of the article is to identify the impact of information logistics on the development and functioning of selected, contemporary logistics concepts.
\end{abstract}

Keywords: logistics of information, information logistics, logistics concepts

\section{Introduction}

Contemporary economy is characterised by variability, a fast pace of growth and great competitiveness. These circumstances render the task of building a competitive advantage a challenging one, and even once such advantage is attained, its maintenance raises significant issues. The economic environment of the $21^{\text {st }}$ century necessitates a search for new and often innovative means of company management, including production, storage, and distribution. This, in turn, fuels the development of logistics and logistics strategies. The logistics strategies that have been created and evolved within the last 20 years are based primarily on technological advances and implementation of modern means of acquiring, storing and processing data, as well as on ensuring the quality of information used in managerial and decision-making processes. 
The sources of obtaining a competitive advantage are rapidly changing, which means that to remain competitive, company owners need to make accurate, on-the-spot decisions, deviate from their previously established habits and make fundamental changes to the assumptions underlying the functioning of their businesses (McGrath, 2013). Hence, the importance of logistics of information, which plays a crucial role in the way in which companies operate on the market and build a competitive advantage (Weiland, 2016).

The purpose of the article is to identify how information logistics affects the growth and functioning of the contemporary logistics strategies. Furthermore, the article foregrounds information logistics as a key component of selected, contemporary logistics strategies, and discusses the importance of information as a vital resource utilized in building a competitive advantage. The author attempts to give structure and coherence to the terminology relating to contemporary logistics, information and data, all of which are crucial in the emergence of information.

The aim of the article has been attained primarily through theoretical research tools, such as analysis of the relevant literature, including text analysis, a bibliometric study and drawing comparisons. Thus, the article may serve as an introduction to further research into how information logistics shapes innovative means of production and distribution.

\section{Information Logistics}

Information ought to be viewed as a full-fledged resource, since - in parallel to all other resources - it is produced, stored and sold by businesses. However, it must be emphasized that - aside from the above-mentioned characteristics information does possess qualities that differentiate it from traditional resources (Skrzypek, Grela, 2005):

- it is non-exhaustible and does not get depleted whilst it undergoes processing;

- it is substitutable;

- it is complementary;

- it is objective;

- it is virtual;

- it is synergistic;

- it is diverse;

- finally, information may be multiplied and transferred across space and time without any limitations or subjectivity of assessments.

One of the most important properties that differentiate information from other resources is the fact that it does not get depleted whilst it undergoes processing or when it is used during production (for instance, in the decision-making process). In consequence, information can be used by multiple agents simultaneously and does not require restoration. However, the inexhaustibility of information does not mean it cannot become outdated - the speed at which information is currently being produced dramatically reduces the span of its lifecycle.

Another equally important quality setting information apart from other resources is its virtuality, which means that it is not inextricably tied to any given storage 
medium. The same information may be carried by multiple storage media without affecting its value to the recipient. The mentioned virtuality is closely connected with its ability to be multiplied ad infinitum across both time and space. Information can be transferred from one storage medium to another, as well as between recipients regardless of the distance that separates them.

Appropriate logistics is required for information to be processed as a resource. Logistics refers to any intentional human activity, whether it is business-related or not. The aim of logistics is to direct the flow of resources within a company, as well as between collaborating organizations along the logistics chain and channels (Chaberek, 2005). Information is one of these resources. At present, every action taken by a business involves a wave of information. The way in which a company uses this resource should be profitable, efficient and effective. The turbulent nature of today's economy makes these goals particularly challenging, hence, for a business to build a competitive advantage, it is crucial to utilize logistics as a means of rationalizing the base processes (Szmelter, 2013).

Information handling within logistics leads primarily to the emergence of systems designed to ensure acquisition, flow and storage of information; further, these systems facilitate appropriate realization of the primary and ancillary processes. However, it needs to be stressed that acquisition, flow and storage of data also fall within the scope of the logistics of information. The process of creating information requires data as one of the most crucial inputs, which justifies the inclusion of data as part of information logistics. For data to be utilized within information logistics, multiple sources of acquiring / creating data need to be integrated with multiple recipients of the said data, which process often occurs in real time. This frequently manifests itself as telematics, that is systems of data acquisition and transfer. These processes cannot be appropriately performed unless there is adequate equipment required for their realization, as well as appropriate technical and organizational solutions. The aim of the logistics of information and data is to provide the required information of appropriate quality, at an appropriate time and place, in an adequate amount and at an acceptable price. If stores of information are to be used profitably, efficiently and effectively, it is necessary for a business to design its own system of supplying information. Such a system would support the decision-making processes by supplying appropriate information - i.e., resources - necessary for the realization of this process. It is impossible to acquire the necessary repository of information without specifying its source first. By analyzing the information used by companies, it is clearly observable that only a fraction of the said information is understood and processed. Thus, business-owned information may be likened to an iceberg, whose greater part remains unseen and thus unused (Wit, 2008). Logistics of information brings to the fore the importance of making businesses aware of the potential that information holds and demonstrates means of acquiring and processing data with the goal of obtaining information. If obtained in accordance with the fundamental assumptions laid out by information logistics, information may contribute to the process of building a competitive advantage. 


\section{Contemporary logistics - evolution or revolution?}

The starting point for any discussion regarding the evolution - or, possibly, revolution - in logistics is, first, to define the primary phenomena relating to it, that is, innovation, revolution and evolution, and second, to juxtapose them in reference to strategies used in logistics.

There are multiple definitions of the term innovation within the relevant literature, which often raises doubts as to whether a given solution or strategy can be described as innovative, or whether it merely bears hallmarks of innovativeness. Literary sources often refer to the concept put forward by Schumpeter in the 1960s, who defines business innovation by enumerating the following qualities:

- it should either better the existing products and introduce new ones;

- it should improve the existing means of production and introduce new ones;

- it should rejuvenate the existing sales markets, as well as search for and open new sales markets;

- it should improve the processes underlying the organization of production;

- it should utilize new means of sales and improve the existing ones;

- it should use new resources and materials.

Rogers and Pichlak suggest an alternative definition, specifically, they view innovation as consisting in an introduction of a new idea, behaviour, product, service, strategy, project or any type of solution, which - from the perspective of the target user or the innovator - is perceived as novelty (Kruczek, Przybylska, Żebrucki, 2015). Hamel (2006) furnishes yet another concept of innovation and its effects on the process of building a competitive advantage, namely, he claims that innovation ought to:

- reduce the costs and increase the operational speed without altering the performance of tasks - operational innovation;

- design and create new products and services - product and service innovation;

- introduce a new perspective on the relationship obtaining between a business and the sales, distribution and supply markets - strategy innovation;

- introduce groundbreaking, novel strategies of organizing labour within a business by rearranging the methods of control, motivation, decision-making, etc. - management innovation.

Bujak and Zając (2011) offer a summary that is highly pertinent to the views presented herein, as they tie innovation inextricably to such phenomena as change, novelty, reform or unprecedented ideas. According to these researchers, what qualifies as innovative is a wide spectrum of technical, organizational and societal facts, processes and phenomena.

The competitiveness of contemporary markets makes innovations indispensable in the following domains of operation: managerial, economical, manufacturing, processual, etc. The primary goal of introducing innovations is to acquire a competitive advantage whilst maximizing the satisfaction of the customers and recipients of the said innovation, both within and outside of a given company.

It is innovations that have been the driving force behind the rapid growth of marketing strategies in management, organization, economy and, finally, in the interdisciplinary domain referred to as logistics. However, as already 
mentioned, innovation does not equal novelty, rather, it may manifest itself as a fundamental reorganization of the already existing processes, systems, components, products, services and the like. Hence, it is crucial to investigate in detail whether what we are witnessing within the sphere of logistics may be more aptly described as a revolution or an evolution.

The Polish Language Dictionary (www1) defines evolution as (self-translation):

- a process observed in the natural environment across generations consisting in changes in the structure of the existing organisms and creation of new organisms;

- a process of transforming, transitioning into more complex states;

- a process of gradually-occurring social changes, from simple forms towards perfected ones.

These definitions share certain similarities, such as: emphasis on the gradual nature of the said changes, improvement of the existing components (products, services, processes, systems) and their transformation into new forms that imbue them with new properties. On the opposite end of the spectrum there is revolution, which is defined by the Polish Language Dictionary (www2) as "a process of precipitous changes in a specific area, which changes are accompanied by a rejection of the existing solutions and introduction of new, better procedures in their place".

While analyzing the definitions adduced above, it is salutary to refer to the history of industrial revolutions. It is commonly assumed that the invention of the steam engine towards the end of the $17^{\text {th }}$ century constitutes the first industrial revolution. This invention mechanized and automatized labour to the exclusion of animals and human workers, which was undoubtedly revolutionary. The second industrial revolution dates back to the beginning of the $20^{\text {th }}$ century and was brought about by the implementation of the means of mass production - primarily the conveyor-belt and the adoption of electrical energy to drive motors. Similarly to what happened throughout the first industrial revolution, the new inventions replaced the existing technologies.

The third industrial revolution happened relatively recently, that is in the 1970s, and it was strictly connected with the introduction of electronic systems and modern information technologies that allowed manufacturing process to be automated.

The fourth industrial revolution - under the name of Industry 4.0 - is said to have begun several years ago (Hanower, 2012). According to many global market practitioners, the fourth industrial revolution will be based on: i) artificial neural networks that enable machines to learn, ii) a widely accessible and highly-developed RFID technology, iii) already existing information technology systems that assist the design procedures, iv) optimization and bolstering of the decision-making processes. However, the greatest emphasis here is placed on intelligent artificial agents, that is, "the Internet of Things" (IoT).

At this stage, it is necessary to elaborate on the aforementioned distinction between economic revolution and evolution, which raises the question whether the already existing and fully-operational solutions and procedures are going to be replaced altogether, or whether they are going to be merely updated and reorganized. 
Many of these components already exist, and their underlying concepts were created primarily through the process of change and evolution. The analogous invention - that of the internal combustion engine - is a telling exemplar of such developments. It was undoubtedly transformative in many domains of life, however, it did not initiate another industrial revolution, rather, it represented merely a step in the evolution of the steam engine. In a similar vein, the current changes in economy - such as the increasing reliance on the Internet, RFID, EDI and multiple other technological and informational solutions - have been in operation for many years and were connected primarily to the third industrial revolution. What we are witnessing at present and what will, in all likelihood, continue to impact the economy for the coming decades is innovative means of utilizing the web, intelligent, self-learning networks, and the emergence of smart devices which are part of the Internet of Things. All this, however, is a long-term, gradual process that does not disrupt the existing system, but rather updates it.

\section{The role of logistics of information in selected contemporary logistics strategies}

As observed by Borowiecki, Jaki and Kaczmarek (1998), some of the distinguishing elements of the business operating with the contemporary market are:

- changeability resulting from the need to constantly adapt to the fluctuating situation on the market;

- operating in an environment characterized by a high degree of risk and uncertainty;

- economic rationality of the constant, professional operations performed by a business;

- the need to incessantly self-improve and retain innovativeness and the entrepreneurial nature of operations.

Businesses that want to satisfy the demands of contemporary markets have to expand beyond their standard operational procedures, habits and manufacturing schemata, since stagnation is likely to either leave them behind their competitors, or lead to bankruptcy. The necessary consequence of these circumstances is the pursuit of innovation across multiple domains and implementation of modern technologies.

According to Borges (1985), the contemporary economy should focus increasingly on the process of rationalization, placing an emphasis on the following phenomena in concordance with the pace of technological advancement:

- mechanisation and automation;

- organization of activities and structures;

- controlling and planning of the manufacturing process;

- planning employment;

- informing and communicating.

In times of technical and technological growth, rationalization revolves not only around the rationalizations of technology, but also around ancillary rationalization, which is primarily concerned with the domain of information supply. 
This has two causes: first, the role of information stores is becoming increasingly important in the functioning of businesses; second, there is a growing awareness of the impact that processes subsidiary to the main process (such as manufacturing), must be equally efficient (Chaberek, 2011). What integrates all flows is the logistics of information.

Logistics, including the logistics of information, is defined by M. Chaberek (2011) as "a process that aims at servicing any rational human activity which comes into being with a purpose of actualizing a certain objective; this process consists in providing the necessary resources (...) in such a way as to make the means of attaining the primary goal efficient, effective and profitable".

Taking into account this definition in relation to logistics, what needs to be identified first is the overall business strategy; only then it is possible to start building and adjusting a logistics strategy designed to support realization of the goals of the overall business strategy. According to Bujak (2014), contemporary innovative concepts and strategies should take into consideration the following factors:

- growing customer expectations;

- development of new technologies;

- globalisation;

- development of online economy;

- emphasis on cost reduction;

- changeability and the necessity to deal with information deficiencies;

- increase in risk and emphasis on security;

- efforts towards a well-balanced development;

- lack of qualified personnel.

However, as reported by Wieczorek (2015), one should bear in mind that, in practice, it is impossible to create a perfect logistics strategy, therefore, businesses ought to focus only on the most important components while creating the said strategy and adjusting it to their needs. Selecting and modifying a strategy in such a way is likely to enable a company to build a stable competitive advantage.

Table 1 included below presents five selected strategies within logistics that have been created and implemented over the last 20 years. The goal of this juxtaposition is to offer a profound insight into how information logistics affects the emergence and form of innovative means of production and distribution.

Contemporary logistics strategies that have emerged within the last 20 years as well as the latest ones, the prime example of which being the aforementioned Internet of Things -- are founded on acquisition and processing of data and information. The changes that are currently occurring in the business environment foreground the importance of the logistics of data and information, which - although heretofore playing merely an ancillary role - has now become a crucial, integrating and leading factor. 
Table 1. Juxtaposition of contemporary strategies in logistics

\begin{tabular}{|c|c|c|c|}
\hline Strategy & Basic assumptions & $\begin{array}{l}\text { Desired results for } \\
\text { the company }\end{array}$ & $\begin{array}{c}\text { The importance } \\
\text { of information logistics } \\
\text { for the implementation } \\
\text { and functioning of the strategy }\end{array}$ \\
\hline 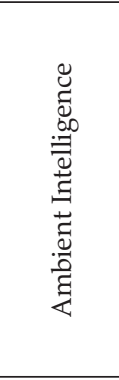 & $\begin{array}{l}\text { Fusing the already existing } \\
\text { technologies and devices } \\
\text { in order to create complex } \\
\text { systems and intelligent } \\
\text { networks that will enable } \\
\text { automation of operation. }\end{array}$ & $\begin{array}{l}\text { Automation of the produc- } \\
\text { tion line, self-renewing } \\
\text { storage supplies. } \\
\text { Automation of process } \\
\text { management. }\end{array}$ & $\begin{array}{l}\text { The logistics of information } \\
\text { is of crucial importance } \\
\text { as a result of the necessity } \\
\text { to acquire and process data } \\
\text { in real time from multiple } \\
\text { sources of measurement. } \\
\text { This data is subsequently } \\
\text { forwarded to numerous } \\
\text { recipients (systems, databases, } \\
\text { etc.) in order to derive useful } \\
\text { information from them. }\end{array}$ \\
\hline 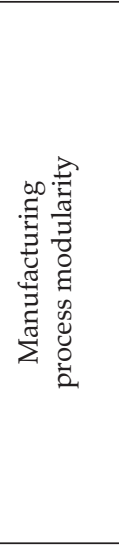 & $\begin{array}{l}\text { A fusion of standardization } \\
\text { and elasticity comprising } \\
\text { the final product assembly } \\
\text { composed of a limited } \\
\text { number of prefabricated } \\
\text { subcomponents (modules). } \\
\text { The process of assembling } \\
\text { subsystems into a complex } \\
\text { product or process, which } \\
\text { subsystems may be } \\
\text { developed irrespectively } \\
\text { of one another and which } \\
\text { offer the additional } \\
\text { benefit of being amenable } \\
\text { to disassembly and recon- } \\
\text { struction. }\end{array}$ & $\begin{array}{l}\text { Utilization of the econom- } \\
\text { ics of scale, manufacturing } \\
\text { of multi-variant products } \\
\text { within time frames satis- } \\
\text { factory to the customer. } \\
\text { Introduction of systems } \\
\text { expediting and facili- } \\
\text { tating product design } \\
\text { and updates, process opti- } \\
\text { mization and the resulting } \\
\text { cost-reduction throughout } \\
\text { the lifespan of a product. }\end{array}$ & $\begin{array}{l}\text { Information logistics } \\
\text { plays an important role } \\
\text { in the product design process } \\
\text { and allows a more efficient } \\
\text { flow of information between } \\
\text { the units responsible for } \\
\text { the delivery of particular } \\
\text { product components awaiting } \\
\text { assembly. }\end{array}$ \\
\hline 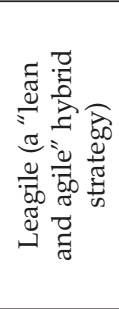 & $\begin{array}{l}\text { A combination of "lean" - } \\
\text { efficient at physical } \\
\text { transfers - and "agile" - } \\
\text { efficient at responding } \\
\text { to the demands of the mar- } \\
\text { ket - strategies. }\end{array}$ & $\begin{array}{l}\text { Delivery chains are } \\
\text { shortened and the ability } \\
\text { to manufacture different } \\
\text { products in the factory } \\
\text { is retained. }\end{array}$ & $\begin{array}{l}\text { Delivery chains based } \\
\text { on the idea of leagile are char- } \\
\text { acterized by highly-developed } \\
\text { infrastructure, control over } \\
\text { and sharing of information } \\
\text { along the entire chain (usually } \\
\text { managed by the chain leader), } \\
\text { as well cooperation between } \\
\text { the suppliers. }\end{array}$ \\
\hline 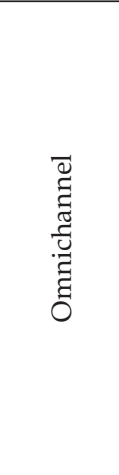 & $\begin{array}{l}\text { This strategy constitutes } \\
\text { the next step in the devel- } \\
\text { opment of e-commerce. } \\
\text { It integrates all channels } \\
\text { of information flow } \\
\text { across all sales platforms } \\
\text { in such a way as to enable } \\
\text { the customer to derive } \\
\text { the same amount } \\
\text { of pleasure from shopping } \\
\text { regardless of which sales } \\
\text { platform he chooses } \\
\text { to initiate and finalise his } \\
\text { purchase. }\end{array}$ & $\begin{array}{l}\text { The goal is to build } \\
\text { a competitive advantage, } \\
\text { improve the information } \\
\text { flow between the customer } \\
\text { and the company, } \\
\text { and to focus all attention } \\
\text { on the customer. }\end{array}$ & $\begin{array}{l}\text { Omnichannel strategy } \\
\text { involves using a unified data- } \\
\text { base in order to integrate all } \\
\text { flows of information between } \\
\text { the customer and the com- } \\
\text { pany, which renders logistics } \\
\text { of information crucial. }\end{array}$ \\
\hline
\end{tabular}




\begin{tabular}{|c|c|c|c|}
\hline Strategy & Basic assumptions & $\begin{array}{l}\text { Desired results for } \\
\text { the company }\end{array}$ & $\begin{array}{c}\text { The importance } \\
\text { of information logistics } \\
\text { for the implementation } \\
\text { and functioning of the strategy }\end{array}$ \\
\hline 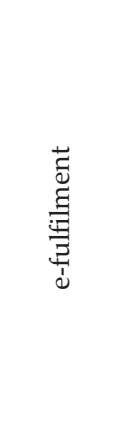 & $\begin{array}{l}\text { This strategy was } \\
\text { created for the purposes } \\
\text { of e-commerce, and its } \\
\text { primary goal is to handle } \\
\text { all aspects of delivering } \\
\text { logistics services ordered } \\
\text { online, including their } \\
\text { realisation and monitoring } \\
\text { of the entire process. }\end{array}$ & $\begin{array}{l}\text { The goal is to make work } \\
\text { less time-consuming, } \\
\text { reduce the amount } \\
\text { of manual labour } \\
\text { and length of maintenance } \\
\text { breaks, to constantly } \\
\text { monitor the process, } \\
\text { supply the customer with } \\
\text { information, provide } \\
\text { satisfactory security } \\
\text { while handling customer } \\
\text { information, personal data } \\
\text { and documents. }\end{array}$ & $\begin{array}{l}\text { Information logistics lies } \\
\text { at the very core of this strategy } \\
\text { and manifests as information } \\
\text { flow between the customer } \\
\text { and the logistics operator. }\end{array}$ \\
\hline
\end{tabular}

Source: (own elaboration based on: Gershenson, Prasad, Allamneni, 1999; Starr, 2010; Mikkola, Skjott-Larsen, 2004; Borgstrom, Hertz, 2011; Prońko, 2012; Przybylska, 2012; Stanek, Zadora, Żytniewski, Kowal, 2012; Zhang, Wang, Wu 2012)

\section{Conclusions}

The contemporary economy is developing at a rapid pace, which - in combination with its fluctuating state - promotes creation of conceptually and structurally innovative logistics strategies and solutions. These are largely based on cutting-edge technologies, and complex systems enabling data acquisition and its subsequent conversion into information. For today's businesses, the said information plays a crucial role since - if handled appropriately through well-organized logistics it facilitates communication and makes a company more competitive on the market. The facts presented herein portray the current global market as a synthesis of evolutionary and revolutionary phenomena that cannot be definitively described as belonging exclusively to either of these categories. This, however, in no way precludes emergence of innovative logistics strategies that draw on the existing solutions, nor does it prevent creation of entirely new concepts whose basic assumptions will be based on the logistics of information.

Further research is going to investigate logistics-related factors shaping innovative and semi-innovative methods of production and distribution.

\section{References}

Borges, A. (1985), Podstawowe etapy działań w przedsięwzięciach racjonalizacyjnych [Basic Stages of Activities in Rationalization Projects], Prace Naukowe Instytutu Organizacji i Zarządzania Politechniki Wrocławskiej, Racjonalizacja Organizacji i Zarządzania $w$ Przedsiębiorstwie [Research Papers of the Institute of Organization and Management of the Wrocław University of Technology, Rationalization of Organization and Management in the Enterprise], Publishing House of the Wroclaw University of Technology, Wrocław, p. 8. 
Bujak, A. (2014), Współczesna logistyka i kierunki jej rozwoju [Contemporary logistics and Directions of Its Development], Logistyka [Logistics], 4, p. 1694.

Bujak, A., Zając, P. (2011), O innowacyjności rozwiązań w obszarze logistyki [On Innovation of Solutions in Logistics]. Logistyka [Logistics], 6, p. 376.

Borgstrom, B., Hertz, S. (2011), Supply Chain Strategies: Changes in Customer Order-Based Production, Journal of Business Logistics, 32(4), p. 363.

Borowiecki, R., Jaki, A., Kaczmarek, J. (1998), Metody i procedury wyceny przedsiębiorstw $i$ ich majatku [Methods and Procedures of Valuation of Enterprises and Their Assets], Publishing House of the Professional School of Business, Kraków.

Chaberek, M. (2005), Makro- i mikroekonomiczne aspekty wsparcia logistycznego [Macroand Micro-economic Aspects of Logistics Support], Publishing House of the University of Gdańsk, Gdańsk, p. 15.

Chaberek, M. (2011), Praktyczny wymiar teorii logistyki [Practical Dimension of the Theory of Logistics], Research Annals of WSB University in Torun, 10, p. 211.

Gershenson, J.K., Prasad, G.J., Allamneni, S. (1999), Modular product design: A life-cycle view, Transactions of the SDPS, 3(4), p. 14.

Hamel, G., Breen, B. (2006), Competing for Future, Harvard Business School Press, p. 88.

Kruczek, M., Przybylska, E., Żebruski, Z. (2015), Znaczenie innowacji w zarządzaniu łańcuchem dostaw [Importance of Innovation in Supply Chain Management], Research Journal of the Silesian University of Technology, Organization and Management, 78(1928), p. 223.

McGrath, R.G. (2013), Transient Advantage, Harvard Business Review, 91(6), pp. 62-70.

Mikkola, J.H., Skjott-Larsen, T. (2004), Supply-chain integration: implications for mass customization, modularization and postponement strategies, Production Planning and Control, 15(4), pp. 352-361.

Prońko, R. (2012), E-biznes - najważniejsze elementy [E-business - Most Important Issues], Studia i Materiaty [Studies and Materials], Miscellanea Oeconomicae, 12, p. 299.

Przybylska, E. (2012), Wspomaganie działalności usługodawców logistycznych nowoczesnymi rozwiazaniami informacyjnymi [Supporting the Activity of Logistics Service Providers with Modern IT Solutions], In: Pyka, J. (Ed.), Nowoczesność przemysłu i ustug - nowe wyzwania [Modern Industry and Services - New Challenges], Scientific Society for Organization and Management, p. 375.

Schumpeter, J. (1960), Teoria rozwoju gospodarczego [Theory of Economic Development], PWN, Warsaw, p. 104.

Skrzypek, E., Grela, G. (2005), Informacja jako zasób niematerialny w warunkach globalizacji [Information as an Intangible Asset in Conditions of Globalization], Annales Universitatis Mariae Curie-Skłodowska. Sectio H, Oeconomia, 39, pp. 22-23.

Starr, M.K. (2010), Modular production - a 45-year-old concept, International Journal of Operations and Production Management, 3(1), p. 8.

Stanek, S., Zadora, P., Żytniewski, M., Kowal, R. (2012), Systemy wszechobecne oraz technologie agentowe [Ubiquitous Systems and Agent Technologies], In: Knosali, R. (Ed.), Innowacje w zarządzaniu i inżynierii produkcji [Innovations in Management and Production Engineering], Polish Society for Production Management, Opole, pp. 843-844.

Szmelter, A. (2013), Business intelligence jako element systemu zaopatrzenia informacyjnego [Business Intelligence As an Element of the Information Supply System], Research Annals of WSB University in Torun, 12, p. 129.

Weiland, D. (2016), Logistyka informacji jako podstawowy element w budowaniu przewagi konkurencyjnej w e-commerce [Information Logistics As a Basic Component in Creating a Competitive Advantage in e-commerce], Economic Studies: Research Journal of the University of Economics in Katowice, 306, pp. 97-110.

Wieczorek, A. (2015), Formułowanie strategii logistycznych a umiejscowienie punktu rozdziału popytu zależnego i niezależnego [Formulation of Logistics Strategies and Location 
of the Dependent and Independent Demand Distribution Point], Zeszyty Naukowe Uniwersytetu Szczecińskiego, 875, Problemy Zarządzania, Finansów i Marketingu [Research Journal of the University of Szczecin, 875, Management, Finance and Marketing Issues], 41(2), p. 536.

Wit, B. (2008), Electronic commerce - budowanie konkurencyjności przedsiębiorstwa w Internecie [Electronic Commerce - Building the Enterprise's Competitiveness on the Internet], Publishing House of the Lublin University of Technology, Lublin, p. 28.

Zhang, Y., Wang, Y., Wu, L. (2012), Research on Demand-driven Leagile Supply Chain Operation Model: a Simulation Based on AnyLogic in System Engineering, The $2^{\text {nd }}$ Research on Demand-driven Leagile Supply Chain Operation International Conference on Complexity Science and Information Engineering, Systems Engineering Procedia, 3.

www1 Stownik jezzyka polskiego [Polish Language Dictionary] PWN, word: evolution. Available from https://sjp.pwn.pl/sjp/ewolucja;2458173.html [Accessed 17 April 2018].

www2 Stownik jezzyka polskiego [Polish Language Dictionary] PWN, word: revolution. Available from https://sjp.pwn.pl/slowniki/rewolucja.html [Accessed 17 April 2018].

\section{Corresponding author}

Dariusz Weiland can be contacted at: d.weiland@ug.edu.pl 